Article

\title{
Analysis of Long-Term Water Level Variation in Dongting Lake, China
}

\author{
Qiaoqian Han ${ }^{1,2}$, Shuanghu Zhang ${ }^{2}$, Guoxian Huang ${ }^{3,4, *}$ and Rui Zhang ${ }^{2,5}$ \\ 1 College of Hydrology and Water Resources, Hohai University, Nanjing 210098, China; hqqjch@126.com \\ 2 State Key Laboratory of Simulation and Regulation of Water Cycle in River Basin, China Institute of Water \\ Resources and Hydropower Research, Beijing 100038, China; sxslzsh@163.com (S.Z.); zr0703@163.com (R.Z.) \\ 3 Department of Hydraulic Engineering, Tsinghua University, Beijing 100084, China \\ 4 State Key Laboratory of Plateau Ecology and Agriculture, Qinghai University, Xining 810016, China \\ 5 Department of Water Resources and Flood Control, School of Civil and Hydraulic Engineering, \\ Dalian University of Technology, Dalian 116024, China \\ * Correspondence: hgx01@mails.tsinghua.edu.cn; Tel.: +86-186-1024-7638
}

Academic Editors: Erik Jeppesen and Martin Søndergaard

Received: 28 March 2016; Accepted: 7 July 2016; Published: 21 July 2016

\begin{abstract}
The water level of Dongting Lake has changed because of the combined impact of climatic change and anthropogenic activities. A study of the long-term statistical properties of water level variations at Chenglingii station will help with the management of water resources in Dongting Lake. In this case, 54 years of water level data for Dongting Lake were analyzed with the non-parametric Mann-Kendall trend test, Sen's slope test, and the Pettitt test. The results showed the following: (1) Trends in annual maximum lake water level (WLM), annual mean lake water level (WL), and annual minimum lake water level (WLm) increased from 1961 to 2014; however, the three variables showed different trends from 1981 to 2014; (2) The annual change trends in Dongting Lake between 1961-2014 and 1981-2014 were found to be from approximately $0.90 \mathrm{~cm} /$ year to $-2.27 \mathrm{~cm} /$ year, $1.65 \mathrm{~cm} /$ year to $-0.79 \mathrm{~cm} /$ year, and $4.58 \mathrm{~cm}$ /year to $2.56 \mathrm{~cm} /$ year for WLM, WL, and WLm, respectively; (3) A greater degree of increase in water level during the dry season (November-April) was found from 2003 to 2014 than from 1981 to 2002, but a smaller degree of increase, even to the point of decreasing, was found during the wet season (May-October); (4) The measured discharge data and numerical modeling results showed the operation of Three Gorge Reservoir (TGR) pushed to influence partly the recent inter-annual variation of water level in Dongting Lake region, especially in the flood and dry seasons. The analysis indicated that the water level of Dongting Lake has changed in the long term with decreasing of range between WLM and WLm, and may decrease the probability of future drought and flood events. These results can provide useful information for the management of Dongting Lake.
\end{abstract}

Keywords: Dongting Lake; Mann-Kendall trend test; Pettitt test; water level; Three Gorge Reservoir

\section{Introduction}

Lakes provide valuable economic resources for human beings and play an important role in environmental and ecosystem services, such as hydrological cycles, the regulation of runoff, and maintenance for abundant biodiversity [1-4]. However, because of the combined impact of climatic change and anthropogenic activities, many lakes around the world are changing [5-8]. Climate warming and anthropogenic activities (e.g., overexploitation, dams and diversions) will adversely affect water quality and quantity. In some regions, wetlands area will decrease or disappear and water tables will decline. Habitats for wetland species will be changed in some lakes [5-8]. These changes may affect the availability of fresh water and regional eco-environments, thus having a critical influence 
on regional sustainable development. Lakes may display different responses to external impacts and have different influences on their littoral zones and habitats [9-11]. In temperate zone lakes with enough rainfall, these changes may increase ground water input, surface water flux, and cause water storage-flooding during wet seasons that may decrease or eliminate the most emergent species and submerged plant cover and affect both the abundance and species diversity $[9,12]$. Changes in the lakes in semi-arid and arid climate zone may lead to buried underwater salt exposure, salinization, a large expansion of the littoral zone [9], desertification, and the reestablishment of dominant vegetation during the dry season, all of which will influence the abundance, biomass and community structure of organisms $[9,12,13]$. As a consequence of climatic change and anthropogenic activities during the past 50 years, Dongting Lake, the second largest freshwater lake in China, has changed in the hydrological regimes (e.g., wetland area and water table) [14-16], associated lake patterns [17], the habitats for important species [18], etc. Some of these changes resulted in many environmental and ecological problems, such as a decline of biodiversity and decline/extinction of some species [15,16,19]. Therefore, the first step is to determine the current hydrologic status and trends in Dongting Lake. Water level, a sensitive marker of change, is an important driving factor for lakes, affecting the lake's physical environment, biota and ecosystem $[9,12,20]$. The duration, timing, magnitude, rate, and frequency of these changes influence the ecological processes and patterns of lakes [21-24]. Any significant change to the water level in a lake will affect its physical processes and biological productivity [20]. However, it needs to be stressed that changes in water levels follow natural patterns that are necessary for the survival of many species [3,25-27]. Only extreme or untimely floods and droughts have adverse effects for biota and humans [28]. Thus, determining and understanding long-term changes in water levels are necessary to protect and restore lakes' ecological services. A significant challenge in this field is existed because of limited of measured data, multiple scales of the object variables, uncertainty of impacted factors, etc.

Numerous studies of the spatial and temporal changes in lake water level around the world have been conducted. Yin et al. [29] used annual maximum water level data to explore the changes in water levels in Hongze lake. Pasquini et al. [30] selected the mean, maximum, and minimum monthly water levels to analyze the fluctuation of water level in proglacial lakes in Patagonia. Motiee and McBean [31] analyzed the change trend in water levels at Lake Superior and tested the slope magnitude using the water balance model. Haghighi and Kløve [32] used the area-volume-depth curve and the water balance model to test the change in water level for lakes. Li et al. [33] selected the daily mean, upper and lower quartiles, and maximum and minimum water levels from June to September for a statistical analysis of intra-annual flood distributions in Poyang Lake. Using the water level and rainfall data during the period of 1961-2010, the analysis by Yuan et al. [34] showed the water level at Dongting Lake decreased significantly during the period of 1961-1980 and there were longer duration in dry season where the water level was below $24 \mathrm{~m}$ during 2003-2010. Compared other sub-periods 1961-1980 and 1981-2002, dam construction was regard as the main factor for the period of 2003-2010. The Three Gorge Reservoir (TGR) started to operate according to 145-175 m scheme after 2009, which brought larger alteration than the 135-156 m scheme before. Therefore, a longer series of measured data are required. Moreover, the quantitative evaluation on the water level variation in Dongting Lake region driven by TGR and other dams may require measured water level, inflow and outflow data at Dongting Lake boundaries, and hydrologic modeling to analyze this kind of problem.

Here we selected seventeen hydrological variables that would reveal statistical characteristics of water level regimes to detect temporal trends in terms of frequency, timing, duration, magnitude, and rate in Dongting Lake over a 54-year period. This article provides an overall view of the long-term changes and sub-period changes in water level regimes through the investigation of the differences in variables in Dongting Lake from 1961 to 2014. The main objectives of this study are: (1) to reveal the long-term trends in water level; (2) to determine the possible change point in the long-term water level data; (3) to estimate the changes in sub-periods; and (4) to perform qualitative and quantitative evaluation the water level variation at Dongting Lake driven by TGR and GZB using the 
measured inflow and outflow discharge data from 2003 to 2014 and two scenarios simulated by our numerical model.

\section{Materials and Methods}

\subsection{Study Area and Data}

Dongting Lake (Figure 1) is located in a basin on the alluvial plain of the Yangtze $\left(110^{\circ} 40^{\prime}-113^{\circ} 10^{\prime} \mathrm{E}, 28^{\circ} 30^{\prime}-30^{\circ} 20^{\prime} \mathrm{N}\right.$ ) [34]. It is fed by four tributaries (Xiang, Zi, Yuan, and Li) and by the Yangtze River's three outlets (Songzi, Hudu, and Ouchi) on the south bank of the Jingjiang reach, and its outflow returns into the Yangtze River from Chenglingji (the sole outlet of the Dongting Lake). Dongting Lake consists of three sub-lakes (east, south, and west), all those sub-lakes include permanent water areas and larger periodically-inundated area. During the wet season, Dongting Lake expands to a large water surface and during the dry season, the periodically-inundated area become lake bottom land. The lake usually reaches its maximum water level in the flood season from June to September and reduces to its yearly minimum surface starting in October. It is located in the subtropical monsoon climate zone and has ample sunshine and abundant rainfall. The annual mean temperature of the lake water is about 16.4-17.0 degrees. Annual total rainfall is about 1200-1400 mm [18]. The wet season is from May to October and dry season is from November to April. The mean annual runoff volume is approximately $3.13 \times 10^{11} \mathrm{~m}^{3}$ [17], $37 \%$ and $55 \%$ of the inlet comes from three outlets and from four rivers, respectively [35].Together with Poyang lake, it is one of two large lakes still linked with the Yangtze River. Dongting Lake is also an important international wetland, with a capacity of more than $1.7 \times 10^{10} \mathrm{~m}^{3}$ [36]. The wetland helps regulate flooding in the Yangtze River as well as the local climate and serves as a water source for industry, agriculture, domestic use and entertainment. The inflows and the water level at the outlet have an important impact on the evolution of the lake. Because Chenglingji station is located at the confluence of the Yangtze and the outlet of Dongting Lake (see Figure 1) and the small longitudinal slopes of the lake's bathymetry and water level, water level changes at Chenglingii station can reflect changes in all of Dongting Lake's water level, although the intense unsteady flow states in the four tributaries and the hybrid river networks linked to Jinjiang may briefly cause some temporary changes along the thalweg of Dongting Lake. Therefore, for this study, we selected daily water level data at the Chenglingji station from 1961 to 2014, as measured by Changjiang Water Resources Commission.

\subsection{Methodology}

In this study, we selected non-parametric methods to detect and confirm trends with confidence, namely the Mann-Kendall (MK) [37,38] test. In addition, we applied the Pettitt test [39] to locate the start of a trend and Sen's slope test [40-42] to estimate the slope magnitude when a linear trend was present in a time series. All tests were conducted in R i386 3.2.1 [43].

MK test: The MK test has been widely used to test stationary statistics against trend statistics in hydrology and climatology [44]. The MK trend test is begun by computing the statistic $S$ using Equation (1)

$$
S=\sum_{i=1}^{n-1} \sum_{j=i+1}^{n} \operatorname{sgn}\left(x_{j}-x_{i}\right)
$$

where $n$ is the number of data; $x_{j}$ and $x_{i}$ are the $j$ th and the $i$ th observation, respectively; and sgn (.) is the sign function, which can be calculated by the following Equation (2):

$$
\operatorname{sgn}\left(x_{j}-x_{i}\right)=\left\{\begin{array}{cc}
1 & x_{j}-x_{i}>0 \\
0 & x_{j}-x_{i}=0 \\
-1 & x_{j}-x_{i}<0
\end{array}\right.
$$




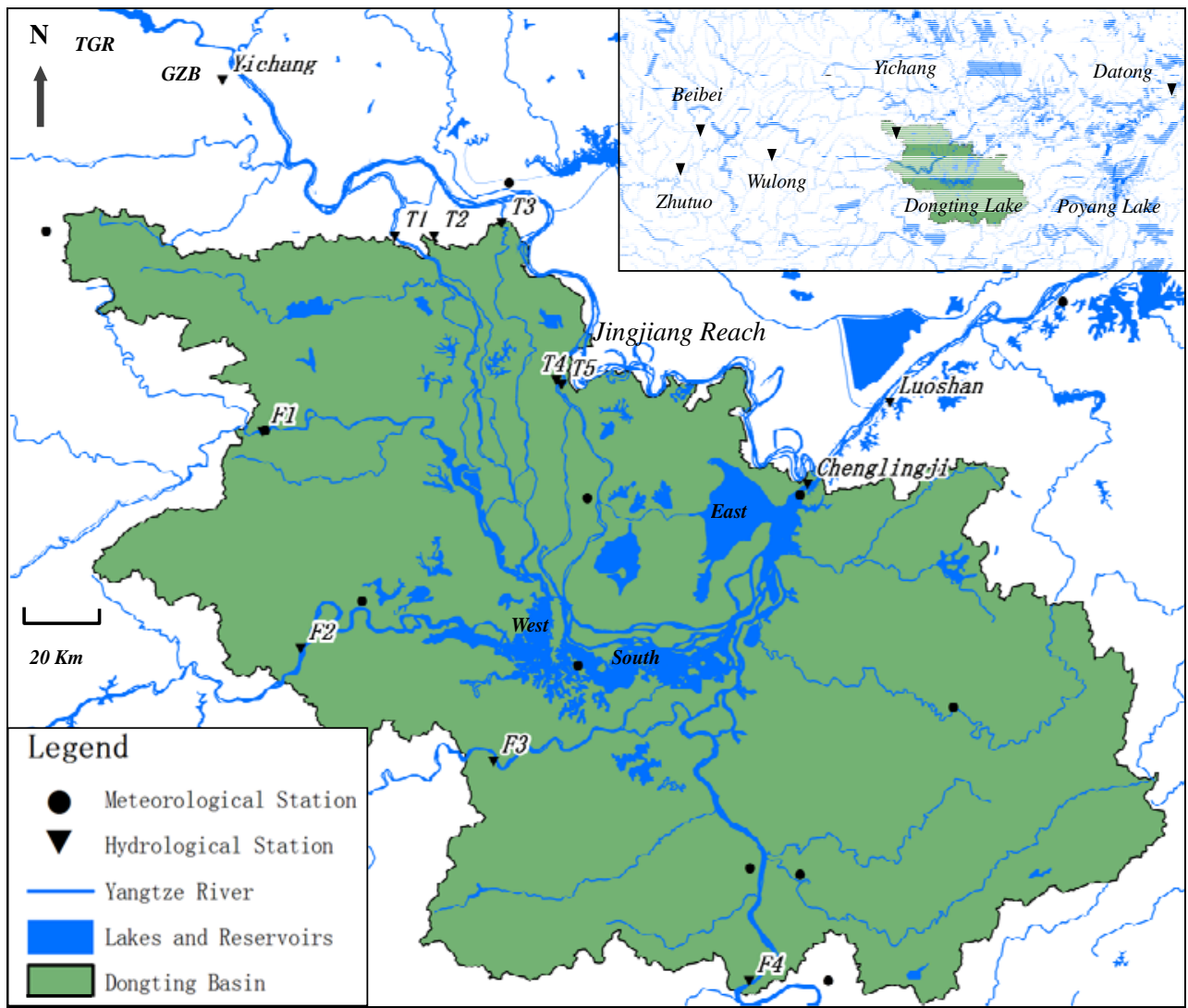

Figure 1. Diagram of the river-lake system in the Dongting Lake. Note: (1) F1, Shimen station at Lishui River; F2, Taoyuan station at Yuanjiang River; F3, Taojiang station at Zishui River; F4, Xiangtan station at Xiangjiang River. Inflow from Four rivers is equal to summarization of F1-F4; (2) T1, Xinjiangkou station at west Songzi River; T2, Shadaoguan station at east Songzi River; T3, Mituosi station at Hudu River; T4, Guanjiapu station at west Ouchi River; T5, Kangjiagang station at east Ouchi River. The inflow from three outlets of Jingjiang is equal to summarization inflow of T1-T5; (3) West, South, and East in Dongting Lake region mean West, South, and East Dongting Lakes.

The statistic $S$ is approximately normally distributed when $n \geqslant 10$. The mean of $S$ is zero and the variance can be calculated by the following Equation (3) [33]:

$$
\operatorname{Var}(S)=\frac{n(n-1)(2 n+5)-\sum_{i=1}^{m} t_{i}\left(t_{i}-1\right)\left(2 t_{i}+5\right)}{18}
$$

where $m$ is the number of tied groups, each with $t_{i}$ tied observations. A set of data that has the same value is a tied group. The test statistic $Z$ can be calculated by the following Equation (4):

$$
Z=\left\{\begin{array}{l}
\frac{S-1}{\sqrt{\operatorname{Var}(S)}} \quad S>0 \\
0 \quad S=0 \\
\frac{S+1}{\sqrt{\operatorname{Var}(S)}} \quad S<0
\end{array}\right.
$$

Thus, in a two-sided trends test, the null hypothesis should be accepted if at the level of significance $(\alpha)$. The positive value of $Z$ indicates an upward trend, and the negative value of $Z$ indicates a downward trend. The absolute of critical value at $\alpha 0.10,0.05$, and 0.01 significance levels of the trend test are $1.64,1.96$, and 2.58 , respectively. 
The MK trend test requires the data series are independent and the presence of autocorrelation would affect the effectiveness of this method. Here we used the "pre-whitened" method [45-47] to eliminate the autocorrelation in data series and then the MK trend test is carried out based on the "pre-whitened" time series.

Pettitt test: The Pettitt test [39] is designed to detect the changing point by testing the change in the mean in the time series, using the statistic $u_{j, N}$ from the Mann-Whitney test to test two samples from the same sample. The statistic $u_{j, N}$ can be calculated by the following Equation (5):

$$
u_{j, N}=u_{j, N-1}+\sum \operatorname{sgn}\left(x_{j}-x_{i}\right) j=2,3, \ldots N
$$

where $u_{j, N}$ and $u_{j, N-1}$ are the U-Statistics at the time of $N$ and $N-1$, respectively; and sgn (.) is the sign function, which can be calculated using Equation (2).

The statistic $k_{j, N}$ can be calculated using Equation (6):

$$
k_{j, N}=\max \left|U_{j, N}\right| 1 \leqslant j \leqslant N
$$

The statistic $p$ can be calculated using Equation (7):

$$
p \cong 2 \exp \left(\frac{-6 k_{j, N}}{N^{3}+N^{2}}\right)
$$

Usually, approximate probability is good for $p \leqslant 0.05$ [48]. Pettitt test is used to detect the changing point, and then the original sequence can be divided into two sub-sequences. For the two sub-sequences, we can use the test to detect both the changing point and the multi-level changing point.

Sen's slope test: The magnitude of the trend slope is computed using the approach developed by Theil [42] and Sen [40]. First, a set of linear trend slopes is calculated for $(1 \leqslant i<j \leqslant 1)$, as follows (Equation (8)):

$$
\beta_{k}=\frac{x_{j}-x_{i}}{j-i}
$$

where $\beta_{k}(1<k<M)$ is the slope; and $l$ is the number of data. $\beta_{k}$ is ranked from smallest to largest and the Sen's slope estimator is calculated using Equation (9):

$$
\beta=\left\{\begin{array}{c}
\beta_{\frac{M+1}{2}} M \text { is odd } \\
\frac{\beta_{\frac{M}{2}}+\beta_{\frac{M+2}{2}}}{2} M \text { is even }
\end{array}\right.
$$

where $\beta$ is the Sen's slope.

\subsection{Determining the Hydrological Variables}

For this study, we chose seventeen hydrological variables to describe long-term changes in the water level of the Dongting Lake: Annual maximum lake water level (WLM); Annual mean lake water level (WL); Annual minimum lake water level (WLm); Range between maximum and minimum water level (RA); Coefficient of variation (Cv); and Mean monthly lake water levels in January (JAN), February (FEB), March (MAR), April (APR), May (MAY), June (JUN), July (JUL), August (AUG), September (SEP), October (OCT), November (NOV), and December (DEC). Cv is used to measure the dispersion of a data series around its mean and to measure the inter-annual variability of the annual mean water level. The seventeen hydrological variables and their measurement units are shown in Table 1. 
Table 1. The hydrological variables abbreviations and their measurement units used in this manuscript.

\begin{tabular}{cccc}
\hline Number & Variable & Definition & Unit \\
\hline 1 & WLM & Annual maximum lake water level & $\mathrm{m}$ \\
2 & WL & Annual mean lake water level & $\mathrm{m}$ \\
3 & WLm & Annual minimum lake water level & $\mathrm{m}$ \\
4 & RA & Range between maximum and minimum water level & $\mathrm{m}$ \\
5 & CV & Coefficient of variation & $\%$ \\
6 & JAN & Monthly lake water level in January & $\mathrm{m}$ \\
7 & FEB & Monthly lake water level in February & $\mathrm{m}$ \\
8 & MAR & Monthly lake water level in March & $\mathrm{m}$ \\
9 & APR & Monthly lake water level in April & $\mathrm{m}$ \\
10 & MAY & Monthly lake water level in May & $\mathrm{m}$ \\
11 & JUN & Monthly lake water level in June & $\mathrm{m}$ \\
12 & JUL & Monthly lake water level in July & $\mathrm{m}$ \\
13 & AUG & Monthly lake water level in August & $\mathrm{m}$ \\
14 & SEP & Monthly lake water level in September & $\mathrm{m}$ \\
15 & OCT & Monthly lake water level in October & $\mathrm{m}$ \\
16 & NOV & Monthly lake water level in November & $\mathrm{m}$ \\
17 & DEC & Monthly lake water level in December & $\mathrm{m}$ \\
\hline
\end{tabular}

\section{Results of Water Level Variation at Dongting Lake}

\subsection{The Results of Lake Water Level from 1961 to 2014}

We gained an overall view of long-term changes in the water level by investigating the differences in yearly time scale variables in Dongting Lake from 1961 to 2014 . We analyzed the trends of WLM, WL, and WLm using the MK trend detection technique and estimated their slope magnitude in three time series using Sen's slope test. Figure 2 demonstrates the three time series of WLM, WL, and WLm. The three time series showed an increasing trend. The respective variations in significant trends of the lake water level regime using slope values, which were calculated by Sen's slope method, are shown in Table 2. The MK test showed a significant increasing trend in WL and WLm on an annual time scale, with a confidence level of $95 \%$. The increasing trend of WLM is not significant $(z=0.6)$. Although Figure 2 reveals changes in the three time series and it is noted that the changes in WLm suggest a greater degree of increase compared to the WLM and WL. Table 2 shows the increasing trend line slope was $0.90 \mathrm{~cm} /$ year, $1.65 \mathrm{~cm} /$ year, and $4.58 \mathrm{~cm} /$ year for WLM, WL, and WLm, respectively.

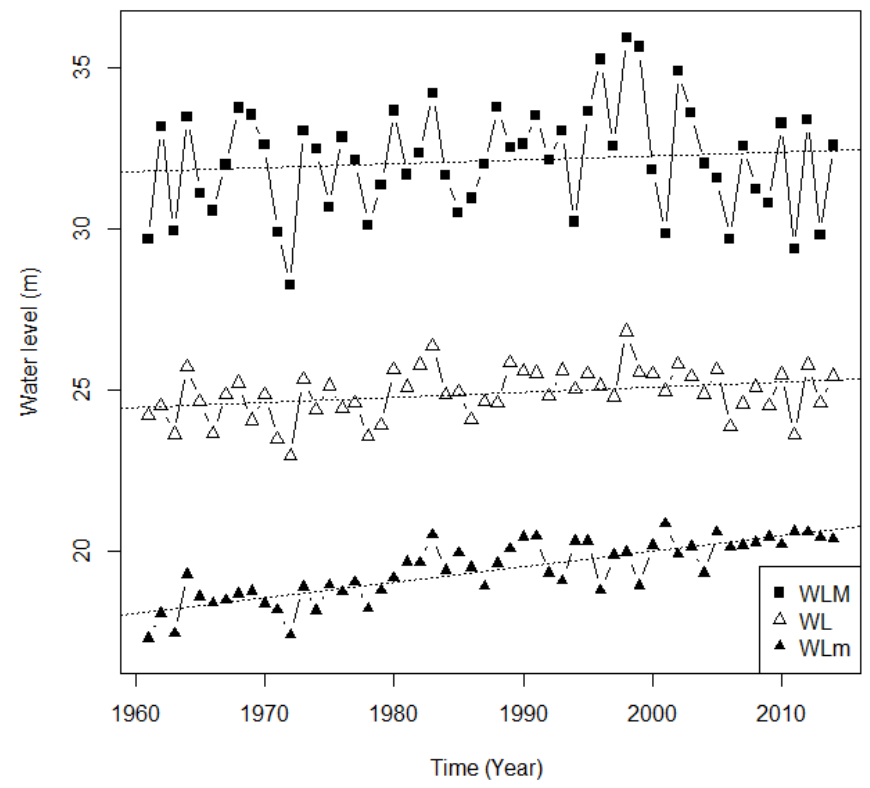

Figure 2. Trends for WLM, WL, and WLm from 1961 to 2014 (note: the black dotted line denotes the linear trend of water levels). 
Table 2. Mann-Kendall statistics and trend slopes of the lake water levels (1961-2014).

\begin{tabular}{ccc}
\hline Variable & $\boldsymbol{Z}$ (MK Test) & Sen's Slope (cm/year) \\
\hline WL & $2.1^{\star}$ & 1.65 \\
WLM & 0.6 & 0.90 \\
WLm & $2.5^{\star}$ & 4.58 \\
RA & $-2.3^{\star}$ & -0.37 \\
CV & $-3.5^{\star}$ & \\
JAN & $4.1^{\star}$ & 3.53 \\
FEB & $3.5^{\star}$ & 3.07 \\
MAR & $2.9 \star$ & 4.29 \\
APR & 1.6 & \\
MAY & 0.6 & 2.68 \\
JUN & $2.1 \star$ & \\
JUL & 0.8 & \\
AUG & 1.3 & \\
SEP & -0.1 & \\
OCT & -1.7 & \\
NOV & -1.4 & \\
DEC & 1.5 &
\end{tabular}

Note: Numbers with ${ }^{\star}$ are significant at $>95 \%$ confidence level. Positive values indicate increasing trends, and negative values indicate decreasing trends.

Significant positive trends (confidence level > 95\%) were identified in water levels for January, February, March, and June; a negative trend (confidence level $>95 \%$ ) was identified in October; negligible negative trends were observed in September and November; and the remaining months demonstrated positive trends without significance (Table 2). Table 2 also shows the slope magnitude of monthly water levels, illustrating similar change properties in water levels when compared with the results of the MK trend test.

Figure 3 and Table 2 show the result of the time series for RA and Cv from 1961 to 2014. There is a significant decreasing trend (confidence level $>95 \%$ ) in the two time series that describes the dispersion of annual water level data.

RA

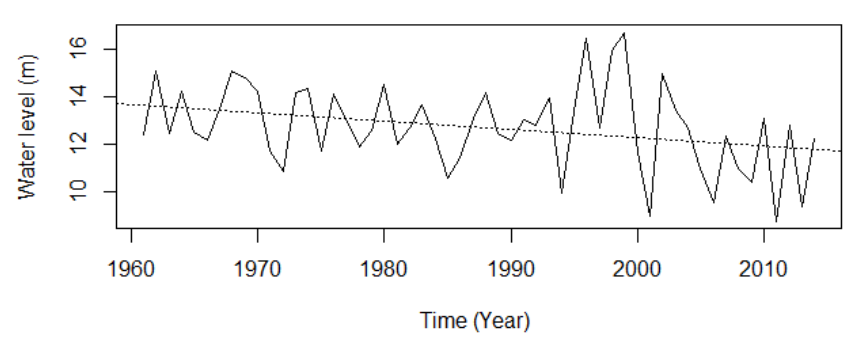

Cv

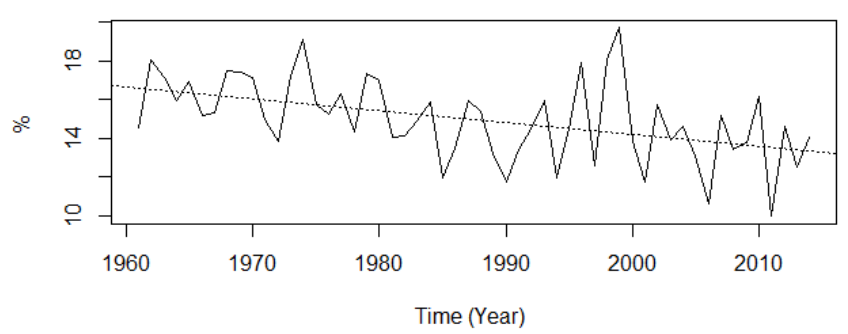

Figure 3. The changes in hydrological variables (RA and Cv) from 1961 to 2014 (note: the black dotted line denotes the linear trend of hydrological variables). 
In this study, abrupt behaviors in water level variables were investigated using Pettitt-test techniques. From 1961 to 2014, the change points were in $1987(p=0.79), 1979(p \ll 0.05)$, and 1980 ( $\mathrm{p}$ « 0.05) for WLM, WL, and WLm, respectively. The approximate probability for the change point for WLM in 1987 is not significant, but the approximate probability for the change points for WL and WLm in 1979 and 1980, respectively, are significant. When we compare the change points according to the Pettitt test and the real situation concerning the construction of the Gezhouba project, which is located on the upper reach of Dongting Lake and may have had some impact on water levels at the Chenglingji station (see Figure 1), we determined that the change point was in the year 1980.

\subsection{The Results of Lake Water Levels from 1981 to 2014}

Figure 4 and Table 3 illustrate the trends in water levels from 1981 to 2014. Table 3 shows a significant increasing trend annually in WLm according to the MK test. The confidence level was $95 \%$. The decreasing trends of WL and WLM were not significant ( $\mathrm{z}$ values are -1.0 and -0.7 ). Table 3 shows a trend line slope of $-2.27 \mathrm{~cm} /$ year, $-0.79 \mathrm{~cm} /$ year, and $2.56 \mathrm{~cm} /$ year for WLM, WL, and WLm, respectively.

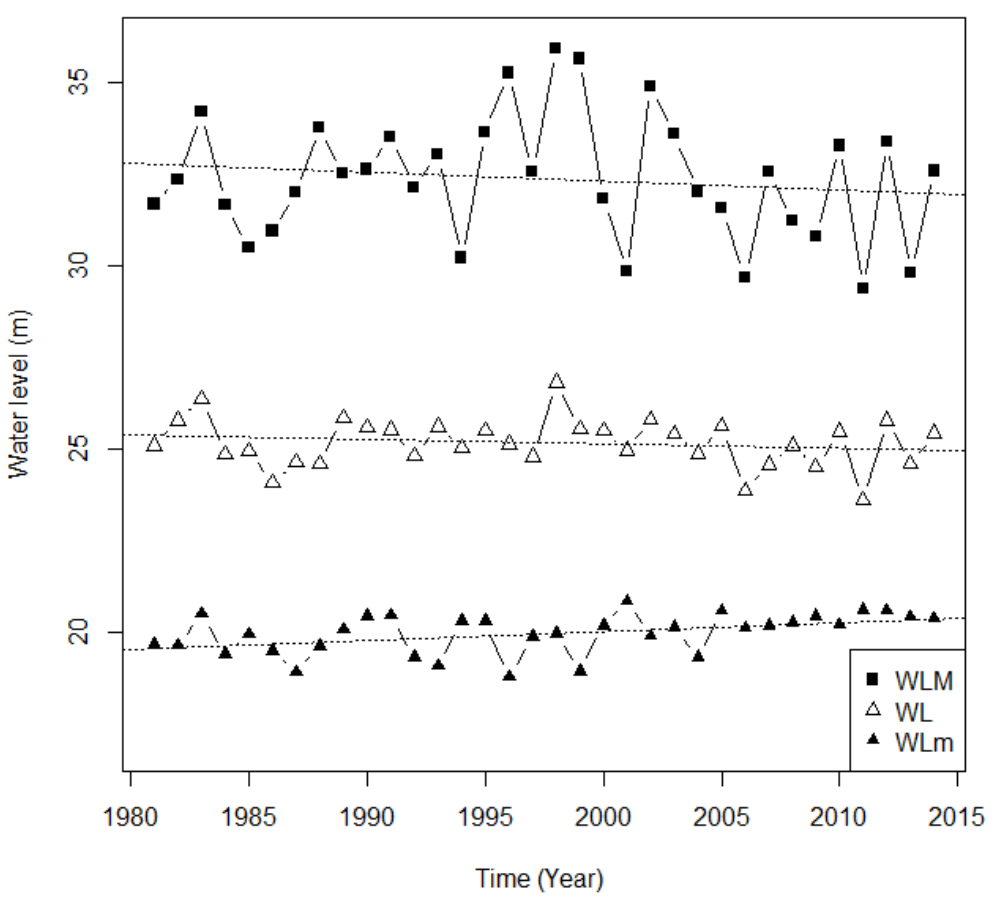

Figure 4. Trends for WLM, WL, and WLm from 1981 to 2014 (note: the black dotted line denotes the linear trend in water level).

Significant positive trends (confidence level $>90 \%$ ) can be identified in water levels for January and May; significant negative trends (confidence level $>90 \%$ ) can be identified in water levels for October and November; a negligible negative trend was observed in April, July, September, and December; and the remaining months demonstrated positive trends without significance (Table 3). Table 3 also shows the slope magnitude of monthly water levels, illustrating similar change properties in water levels when compared with the results of the MK trend test.

Figure 5 and Table 3 show the result of the time series for RA and Cv from 1981 to 2014. There was a negligible decreasing trend in the two variables for the time series describing the dispersion of annual water level data. 
Table 3. Mann-Kendall statistics and trend slopes of lake water levels (1981-2014).

\begin{tabular}{ccc}
\hline Variable & $Z$ (MK Test) & Sen's Slope (cm/year) \\
\hline WL & -1.0 & -0.79 \\
WLM & -0.7 & -2.27 \\
WLm & $2.6^{\star}$ & 2.56 \\
RA & -1.3 & \\
SD & -0.7 & \\
Cv & -0.6 & \\
HR & -1.5 & 2.62 \\
JAN & $2.3 \star$ & \\
FEB & 0.8 & \\
MAR & 0.3 & \\
APR & -0.9 & \\
MAY & 1.7 & \\
JUN & 0.8 & \\
JUL & -0.5 & \\
AUG & 0.0 & \\
SEP & -0.9 & \\
OCT & $-3.8 \star$ & \\
NOV & -1.8 & \\
DEC & -0.7 & \\
\hline
\end{tabular}

Note: Numbers with $\star$ are significant at $>95 \%$ confidence level (positive values indicate increasing trends, and negative values indicate decreasing trends).
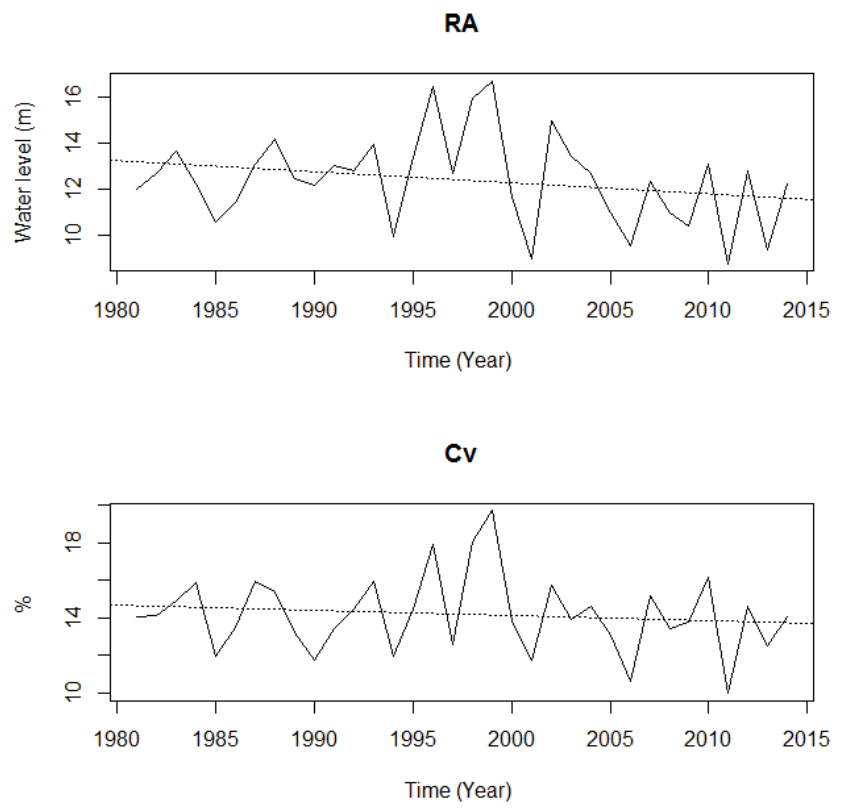

Figure 5. The changes in hydrological variables (RA and Cv) from 1981 to 2014 (note: the black dotted line denotes the linear trend of hydrological variables).

From 1981 to 2014, the change points are in $2003(p=0.31), 2005(p=0.39)$, and $1999(p=0.04)$ for WLM, WL, and WLm, respectively. The approximate probability for the change point for WLM and WL in 2003 and 2005 are not significant, but the approximate probability for the change points for WLm in 1999 is significant. The approximate probability of the change point was in 1999.

\subsection{Comparisons of Water Levels between Three Time Periods}

The variable changes from 1961 to 2014 and 1981 to 2014 require further study of sub-periodic changes in water level. Considering the change points discovered using the Pettitt test, we divided the 
time series into three sub-periods: 1961-1980, 1981-1999, and 2000-2012. Considering the operation of Three Gorges Reservoir (TGR), the time series are divided the time series into three different sub-periods: 1961-1980, 1981-2002, and 2003-2014.

After the normal distribution test and homogeneity test of variance using Shapiro-Wilk [49] and Bartlett test [50], respectively, analysis of variance (ANOVA) [51-53] was performed to investigate the variations of the water level. Table 4 shows that no significant differences in mean water level among three sub-periods divided by the change points discovered using the Pettitt test and the operation of TGR, but there were some differences in mean water level among different months.

Table 4. ANOVA results for the mean values of water level.

\begin{tabular}{ccccccc}
\hline Parameters & Element & Sum of Squares & $d f$ & Mean Square & $\boldsymbol{F}$ & $p$ Value \\
\hline \multirow{2}{*}{1} & Months & 346.08 & 11 & 31.46 & 9.71 & $4.18 \times 10^{-6}$ \\
& Sub-periods & 0.61 & 2 & 0.31 & 0.09 & 0.91 \\
\hline \multirow{2}{*}{2} & Months & 349.04 & 11 & 31.73 & 9.66 & $4.36 \times 10^{-6}$ \\
& Sub-periods & 0.75 & 2 & 0.38 & 0.11 & 0.89 \\
\hline
\end{tabular}

Notes: 1 is the three sub-periods divided by the operation of TGR (1961-1980, 1981-2002, and 2003-2014); 2 is the three sub-periods divided by the change points discovered using the Pettitt test (1961-1980, 1981-1999, and 2000-2014).

Figure 6 shows the comparison between the three sub-periods. To calculate the water level variations quantitatively between the three sub-periods, we first calculated the annual WLM, WL, WLm, and the monthly average water level for the three sub-periods. Then, we compared the first sub-period (1961-1980) with relative differences from the subsequent two sub-periods. The results are shown in Table 5. Clearly, WL and WLm increased in the last two sub-periods but WLM increased over the period 2000-2014 and decreased over the period 2003-2014. However, for the sub-periods obtained via the Pettitt test, the mean monthly water level from 1981 to 2002 increased except for May (decreased) and October (not changed), and the water level from 2003 to 2014 increased except for May (decreased) and September-November (decreased). For the sub-periods obtained via the operation of TGR, the mean monthly water level from 1981 to 1999 increased except for May (decreased), and the water level from 2000 to 2014 increased except for May (not changed) and September-November (decreased).

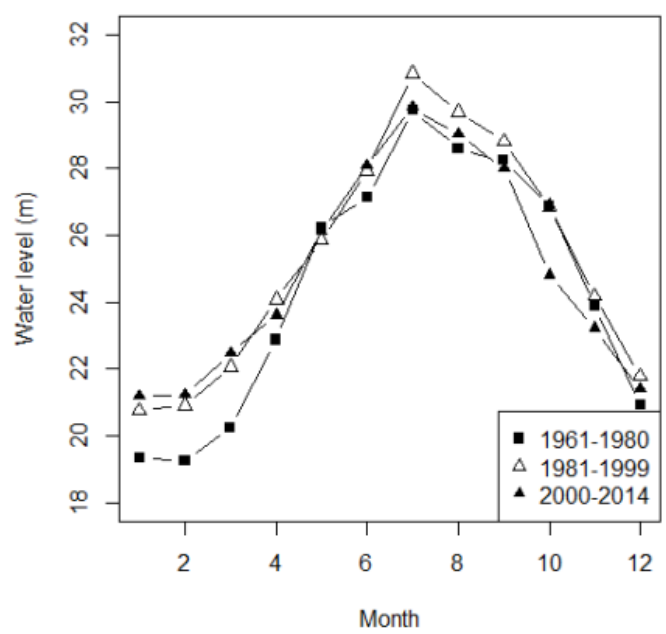

b

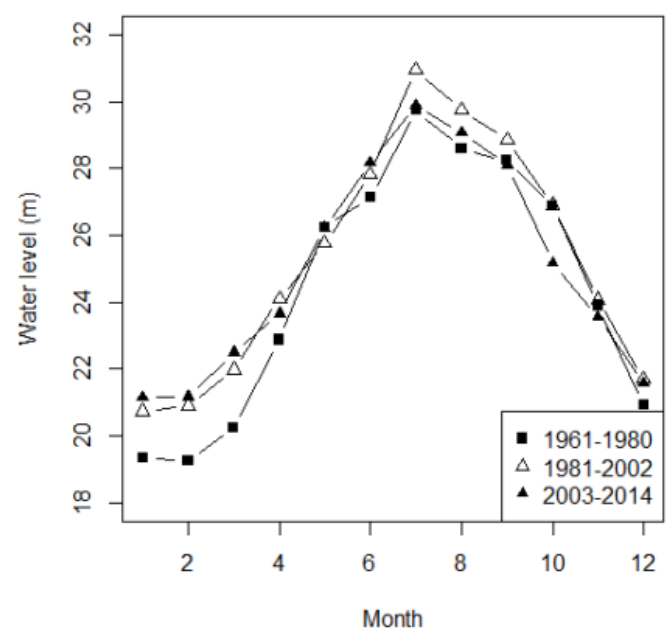

Figure 6. Inter-annual variations in water level during the three sub-periods. 
Table 5. The mean water level for all sub-periods and percentage changes from the first sub-period to the two subsequent sub-periods.

\begin{tabular}{cccccccccc}
\hline & $\mathbf{1 9 6 1 - 1 9 8 0}$ & \multicolumn{2}{c}{$\mathbf{1 9 8 1 - 2 0 0 2}$} & \multicolumn{2}{c}{$\mathbf{2 0 0 3 - 2 0 1 4}$} & \multicolumn{2}{c}{$\mathbf{1 9 8 1 - 1 9 9 9}$} & \multicolumn{2}{c}{$\mathbf{2 0 0 0 - 2 0 1 4}$} \\
\cline { 2 - 9 } & Mean (m) & Mean $(\mathbf{m})$ & $\mathbf{\%}$ & Mean $\mathbf{( m )}$ & $\mathbf{\%}$ & Mean $\mathbf{( m )}$ & $\mathbf{\%}$ & Mean (m) & \% \\
\hline WLM & 31.72 & 32.76 & 3.29 & 31.66 & -0.19 & 32.85 & 3.56 & 31.77 & 0.16 \\
WL & 24.44 & 25.32 & 3.58 & 24.91 & 1.91 & 25.30 & 3.52 & 25.02 & 2.37 \\
WLm & 18.45 & 19.81 & 7.38 & 20.28 & 9.92 & 19.73 & 6.94 & 20.29 & 9.97 \\
JAN & 19.34 & 20.75 & 7.29 & 21.18 & 9.52 & 20.73 & 7.16 & 21.13 & 9.26 \\
FEB & 19.23 & 20.90 & 8.68 & 21.21 & 10.30 & 20.89 & 8.66 & 21.15 & 10.00 \\
MAR & 20.22 & 22.06 & 9.10 & 22.46 & 11.08 & 21.98 & 8.69 & 22.48 & 11.20 \\
APR & 22.87 & 24.07 & 5.25 & 23.60 & 3.18 & 24.10 & 5.37 & 23.65 & 3.42 \\
MAY & 26.23 & 25.88 & -1.33 & 26.13 & -0.36 & 25.76 & -1.79 & 26.23 & 0.00 \\
JUN & 27.14 & 27.94 & 2.95 & 28.09 & 3.48 & 27.84 & 2.58 & 28.19 & 3.85 \\
JUL & 29.77 & 30.85 & 3.63 & 29.84 & 0.23 & 30.97 & 4.03 & 29.89 & 0.41 \\
AUG & 28.59 & 29.70 & 3.88 & 29.02 & 1.51 & 29.77 & 4.13 & 29.06 & 1.66 \\
SEP & 28.24 & 28.83 & 2.09 & 27.99 & -0.88 & 28.87 & 2.23 & 28.11 & -0.45 \\
OCT & 26.87 & 26.87 & 0.00 & 24.80 & -7.69 & 26.90 & 0.12 & 25.18 & -6.30 \\
NOV & 23.90 & 24.19 & 1.21 & 23.22 & -2.84 & 24.08 & 0.76 & 23.55 & -1.48 \\
DEC & 20.93 & 21.78 & 4.06 & 21.40 & 2.23 & 21.71 & 3.71 & 21.56 & 3.00 \\
\hline
\end{tabular}

\section{Impacted Factors Analysis for the Water Level Variations}

\subsection{Impacted Factors Identification and Analysis for the Inter-Annual Variations of Water Level}

The water level in Dongting Lake may be mainly controlled by the water level at Chenglingji station and inflows from four branched rivers and three outlets around Dongting Lake. Due to the backwater effect, the water level at Chenglingji station may partly impacted by the flow discharge and water level at Luoshan station in the Yangtze main stem, which is about $30 \mathrm{~km}$ downstream to the Chenglingji station (see Figure 1). Based on the qualitative analysis above, the daily measured inflow discharge and water level at 12 hydrological stations around Dongting Lake at the period of 1961-2014 are collected and processed to identify and analyze the key driving factors for the water level variation. By comparison with inter-annual variations of flow discharge at three sub-periods, the following observations can be made: (1) In flood season from June to September, there are obvious declines in flow discharge at Yichang and Luoshan stations in Yangtze main stem (Figure 7a,b). There is also obvious reduction in the total inflows (Figure 7c), in which, generally reduction from four branched rivers (Figure 7d) and seriously decline of the inflow from three outlets (Figure 7e) during the period 2003-2014 (black line in the Figure 7). The inflow decline from three outlets may attribute to the inflow reduction to the TGR, operation function of TGR and TGR-induced variation in the river-lake relationship, which is occupied $68.9 \%, 13.9 \%$ and $17.2 \%$, respectively [54]. Compared to the other sub-periods, the 12-year flow declines may mainly be driven by the smaller rainfalls in the controlled catchments. For example, a dry hydrological year appeared with 50-year frequency in 2011. Moreover, the peak flood reduction may partly attribute to flood detention by the large reservoirs at upper reach of Yangtze River and four branched rivers; (2) In dry season from November to March, the additional released flow from large reservoirs, such as TGR, GZB, etc., for hydropower generation, navigation and eco-environmental basic flow, will increase about $1000 \mathrm{~m}^{3} / \mathrm{s}$ and $2200 \mathrm{~m}^{3} / \mathrm{s}$ of flow discharge at Yichang and Luoshan, respectively. Among them, flow increment of $1200 \mathrm{~m}^{3} / \mathrm{s}$ at Luoshan may be mainly produced by early larger rainfall and the releasing flow from dams in the four rivers at the start of flood season (April-June); (3) In early flood season from April to June, additional flow discharge from reservoir releasing for flood control will increase the flow discharge at some degree, especially on the stations at the downstream of TGR in Yangtze main channel; (4) At the end of the flood season, there is an obvious reduction in flow discharge because of the rapid water storage by the large dams. The comparison between the shapes for inter-annual variations at three sub-periods can explain qualitatively the possible combination effects driven by the net rainfall variation from climate changes and dams' operation at some degree. However, only using combined in situ data, it is not easy to evaluate the effects caused by the operations of dams separately and quantitatively. Therefore, 
in subsequent sub-section, a refined numerical modeling is applied to further identify the water level and flow discharge variation linked to the operation of TGR and GZB.

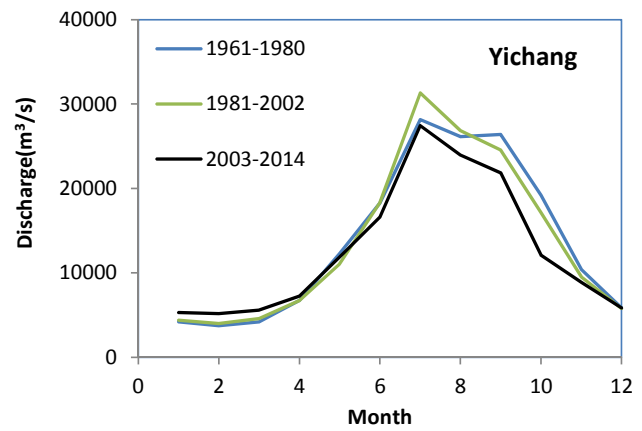

(a) Yichang

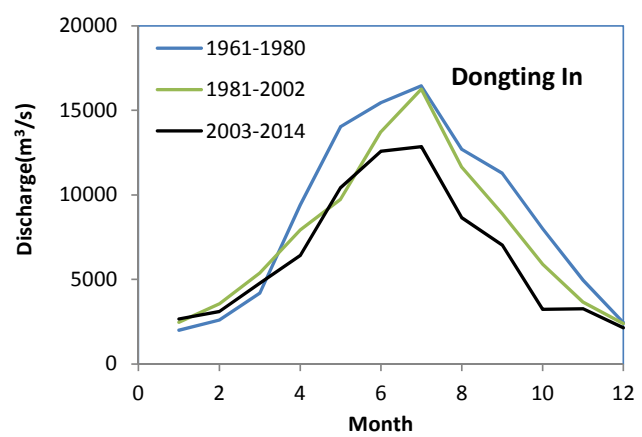

(c) Dongting inflow

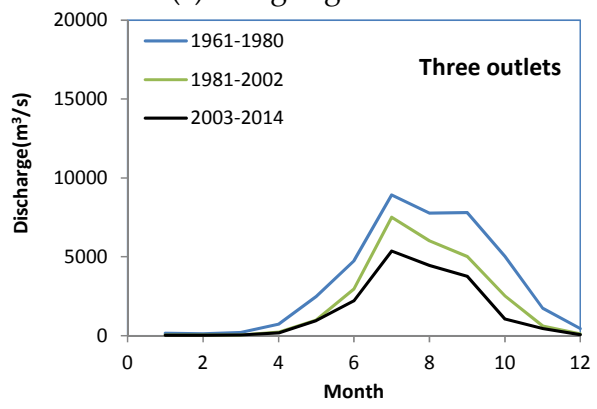

(e) Three outlets

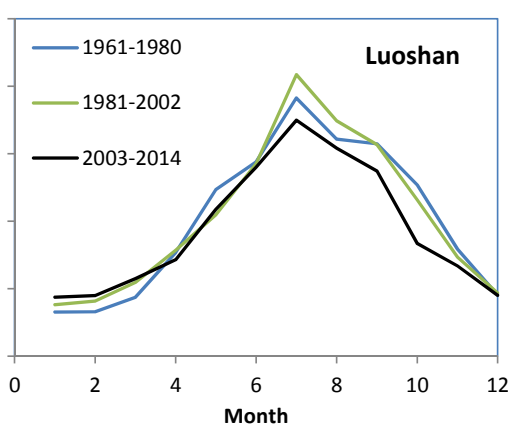

(b) Luoshan

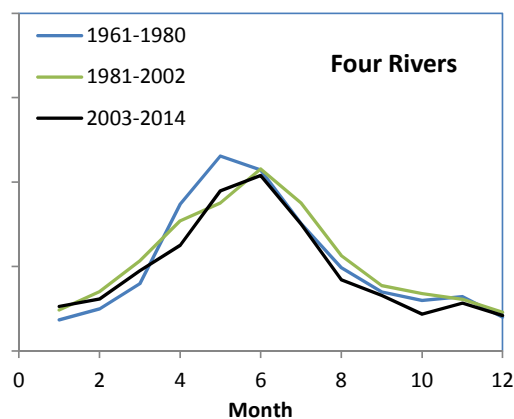

(d) Four rivers

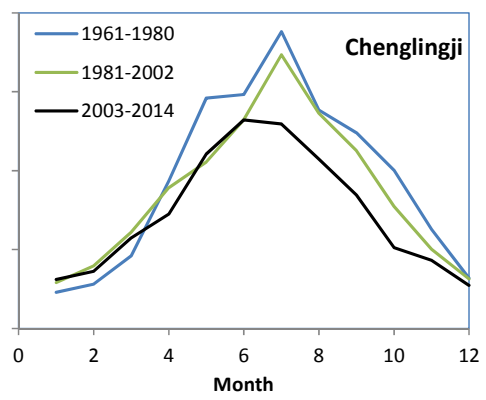

(f) Dongting outflow

Figure 7. Inter-annual variations in flow discharge during three sub-periods (1961-1980, 1981-2002, and 2003-2014). (note: a-f is the variations of Yicheng discharge, Luoshan discharge, Dongting inflow, Four Rivers inflow, Three outlets inflow, and Chenglingji outflow, respectively).

\subsection{Quantitive Identification on the Hydrological Variation Linked to TGD and GZB}

The operation of TGD and GZB may cause the variation in water level and flow discharge at river networks and lakes system from Zhutuo to Yangtze estuary. Considering the main impacted region, our hydrodynamic model domain included the complex Yangtze river-lake-reservoir system from Zhutuo to Datong station, in which, Yangtze main channel, main branches, lakes and inner river networks linked to lake and Yangtze stem are included. There are more than 5700 cross-sections and 220 sub-channels in the model system, and related measured data are used in the model. This indicates the model has a good representativeness in the distribution, linkage and bathymetry of complex river-lake-reservoir system. The verifications showed Nash-Sutcliffe coefficient of efficiency (CE) at 94 controlled stations were large than 0.90 . The details about the model theory, parameters setup, validation and calibration in the Yangtze River were given in the references [55-57]. In order to identify quantitatively the water level and discharge variation at Dongting Lake driven by TGP and GZB, two scenarios are designed and setup in the model system for the third sub-period (2003-2014) including S1. 
There are no construction and operation of TGP and GZB, the water can flow freely from Zhutuo to Datong as same as the natural state before (S2). The two dams operated according to the real situations. After 2009, TGP is operated according to 145 and $175 \mathrm{~m}$ scheme in flood seasons and dry seasons, respectively. The numerical results (2009-2012) in the given stations are presented in Figure 8. After the operation of TGP and GZB, the main variations at Yichang station, which is about $4 \mathrm{~km}$ downstream to the outlet of GZB, are summarized as follows: (1) Because of additional releasing flow from TGR, there is an obvious increasing in flow discharge in pre-floods from May to June and in dry seasons from December to May respectively. The averaged increment during 2009-2012 arrived at $6000 \mathrm{~m}^{3} / \mathrm{s}$ and $1500 \mathrm{~m}^{3} / \mathrm{s}$, respectively; (2) Because of flood detention by reservoirs, there is some reduction during the flooding peaks usually from July to August; (3) At the end of flood from the mid of September to November, in order to guarantee the enough hydropower generation in dry season, the inflows storage by a reservoir will obviously decrease outflow from the reservoir. For example, the reduced flow discharge at Yichang station was $20,000 \mathrm{~m}^{3} / \mathrm{s}$ on 25 September 2011; (4) In general, the operations of TGR and GZB make the flood period earlier than before. Compared to the flow discharge at Yichang, the discharge process at Luoshan, located about $400 \mathrm{~km}$ downstream of Yichang, showed the similar variation trend with smaller variation magnitudes because of hydrodynamic attenuation in the Jingjiang-Dongting systems and flow mixture with inflows from four rivers and three outlets (Figure 8b). The discharge variation in Luoshan will cause a similar variation in the water level at Luoshan and Chenglingji station (Figure 8c,d).

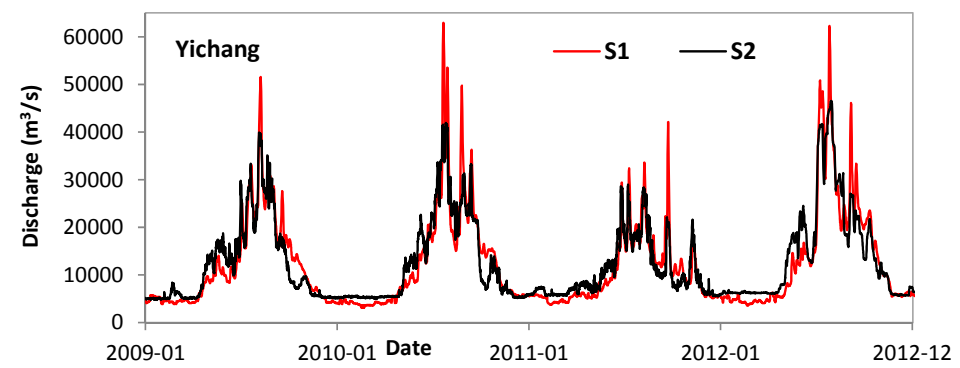

(a) Discharge at Yichang

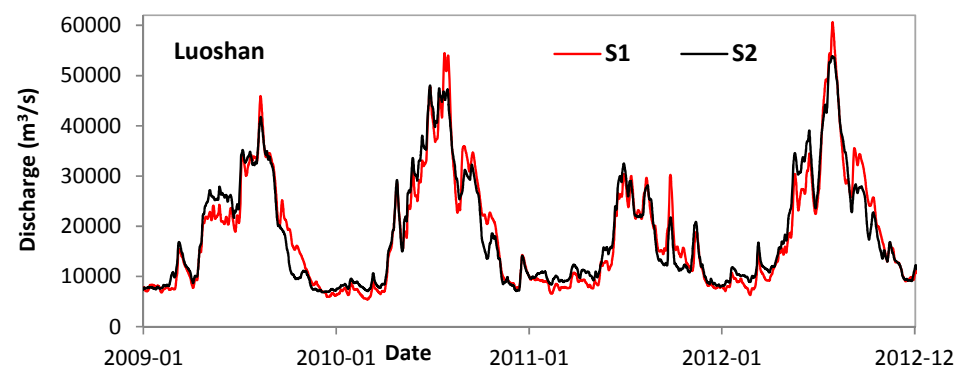

(b) Discharge at Luoshan

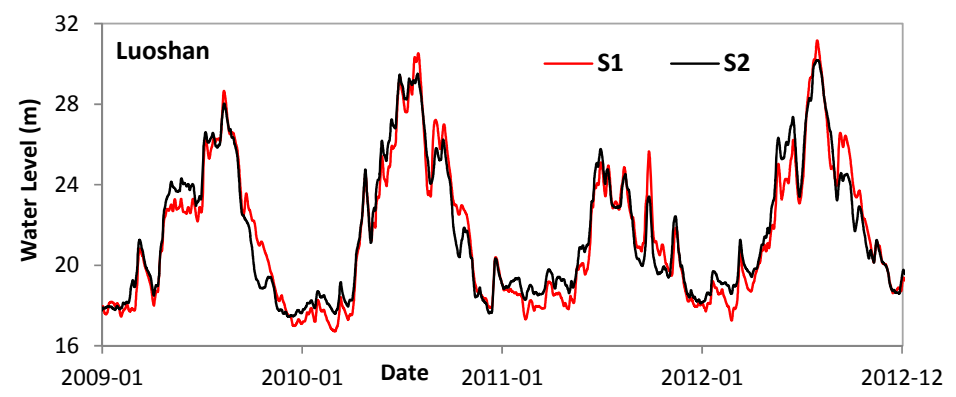

(c) Water level at Luoshan

Figure 8. Cont. 


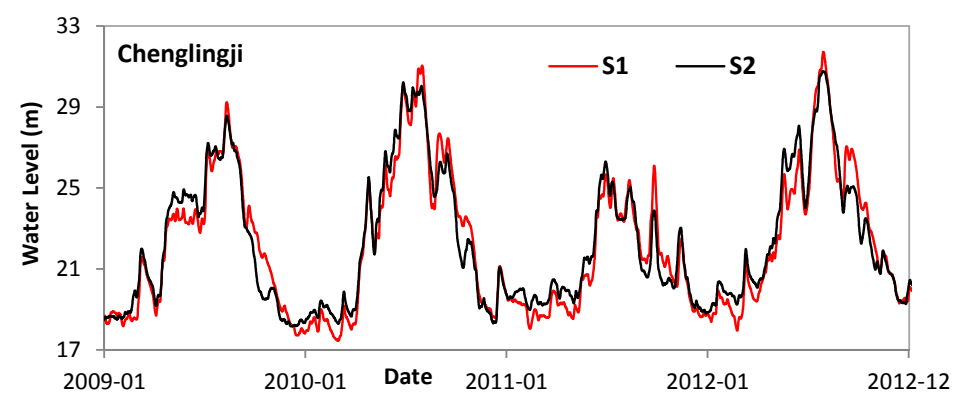

(d) Water level at Chenglingji

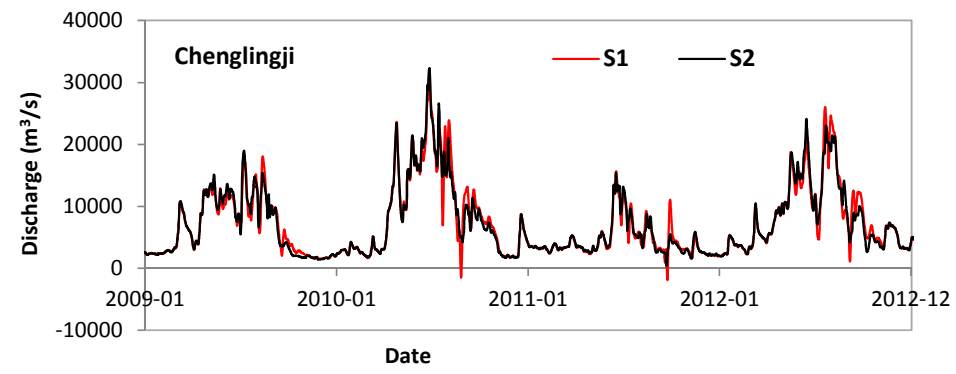

(e) Discharge at Chenglingji

Figure 8. Water level and discharge comparison with and without operation of TGP and GZB. (note: a, b, and $\mathbf{e}$ is the discharge comparison at Yicheng, Luoshan, and Chenglingji, respectively; $\mathbf{c}$ and $\mathbf{d}$ is the water level comparison at Luoshan and Chenglingji , respectively).

The water storage by TGP at the end of the flood altered the flow and water level situations from Yangtze to Dongting Lake based on our modeling results (Figure 8). For example, maximum decrease of the water level at Chenglingji station on 25 September 2011 were about $2.2 \mathrm{~m}$, the duration of this obvious reduction was more than one month till the TGR was filled (Figure 8d). Meanwhile, this reduced water level weakened the backwater effect and even decreased the returned flow from Yangtze stem to Dongting Lake (Figure 8e).

Based on the numerical modeling results, the inter-annual variations with and without operation of TGR and GZB during the sub-period 2003-2014 are presented in Figure 9. After the operation of two large reservoirs, the water level had an averaged about $0.5 \mathrm{~m}$ increment in dry season and $0.3 \mathrm{~m}$ reduction in the flood season. Because of the larger water releasing and storing at the start and end of the flood season compared to other periods, there were relative larger variations in the water level process, and the increasing and reducing magnitudes arrived $0.7 \mathrm{~m}$ and $1.0 \mathrm{~m}$ in May and October, respectively. The $145-175 \mathrm{~m}$ operation scheme was put into practice in 2009 , and the altered magnitude amounted to about $1.2 \mathrm{~m}$ and $2.0 \mathrm{~m}$, respectively (see Figure $8 \mathrm{~d}$ ). Totally, the operation of TGR and GZB, especially the 145-175 m operation of TGR, will alter the Dongting Lake's flood storage functions in floods from four rivers and early floods from upper Yangtze River, respectively, speeding up the flow releasing processes from Dongting to Yangtze River at the end of Yangtze floods. These alterations may bring some impacts on the flood controls, lakebed deformation, aquatic ecosystems, etc. in Dongting Lake and Yangtze River. 


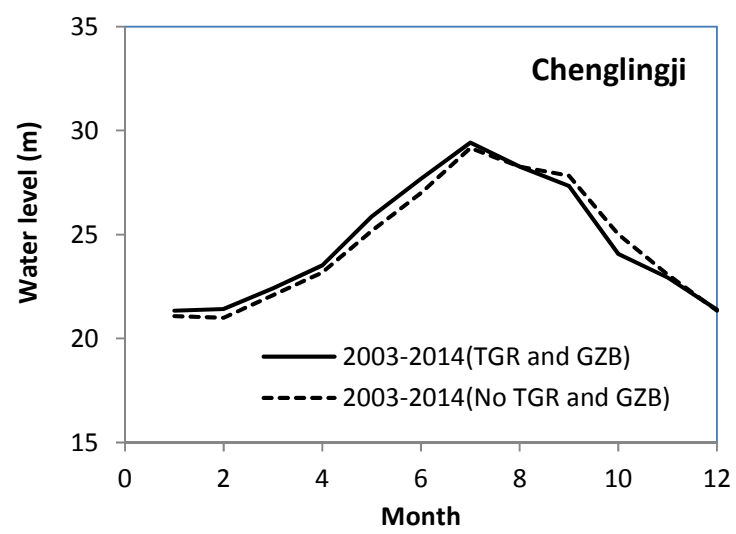

Figure 9. Inner annual water level variation during 2003-2014 at Chenglingji with and without the operation of TGR and GZB.

\subsection{Relationships between the Hydrological Processes and Net Rainfall around the Dongting Lake Region}

The daily measured rainfall and evaporation data measured by $20 \mathrm{~cm}$-diameter evaporating dish at 23 stations are collected from China Meteorological Data Sharing Service System (CMDSS, http://cdc.cma.gov.cn/). The inverse distance weight (IDW) interpolations including four adjacent stations are used to interpolate daily rainfall and evaporation in Dongting basin with $1000 \mathrm{~m}$ cell size. From Figure 10, the annual rainfall in the Dongting region had a small reduction during 2003-2014 compared to the sub-periods 1961-1980 and 1981-2003, while the annual evaporation increased to some degree. However, the water level at Dongting Lake was increasing in dry season, which means the reduced local flow driven by the net rainfall in the Dongting Lake region did not have a significant dominated to the water level in Dongting Lake. Further statistics showed this local flow component only occupied $8 \%$ of total inflows. Moreover, the analysis showed there was slight erosion [58] in the thalweg region of East Dongting Lake and a large deepening in the lower reach of Xiangjiang channel [59] because of the sand mining and water way regulation in the recent ten years. Considering the reasons above, the operations of the large dams were main driving factors for the increasing WL trend at Dongting Lake. With regard to the other aspects, the net rainfall processes in Dongting region at three sub-periods had a well representativeness in flow processes from four branched rivers because of the region adjacency (See Figure 11).

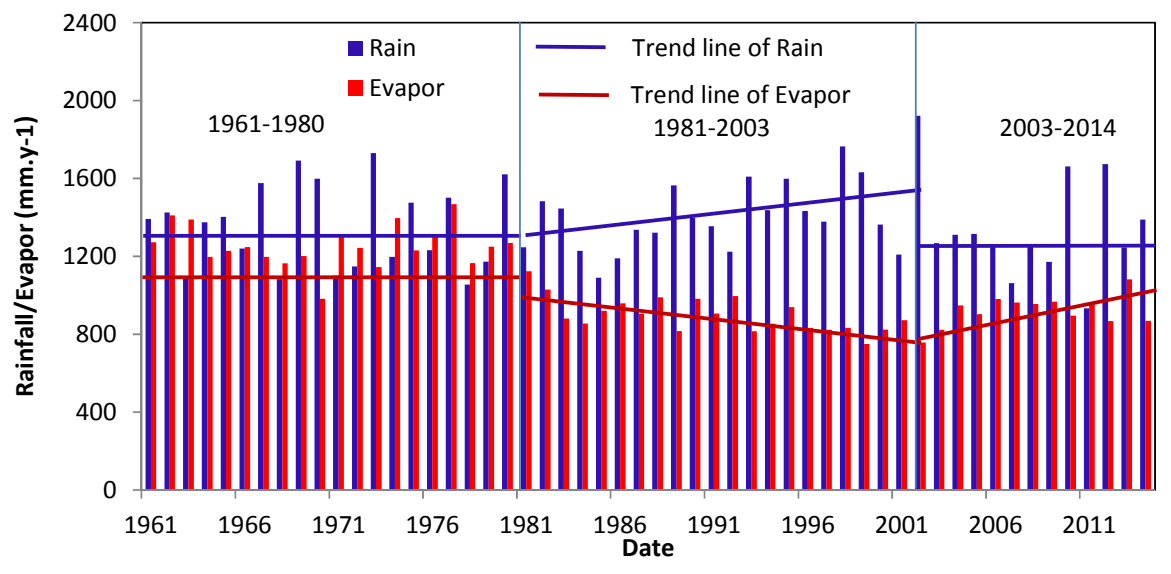

Figure 10. Annual rainfall and evaporation during the period 1961-2014. 


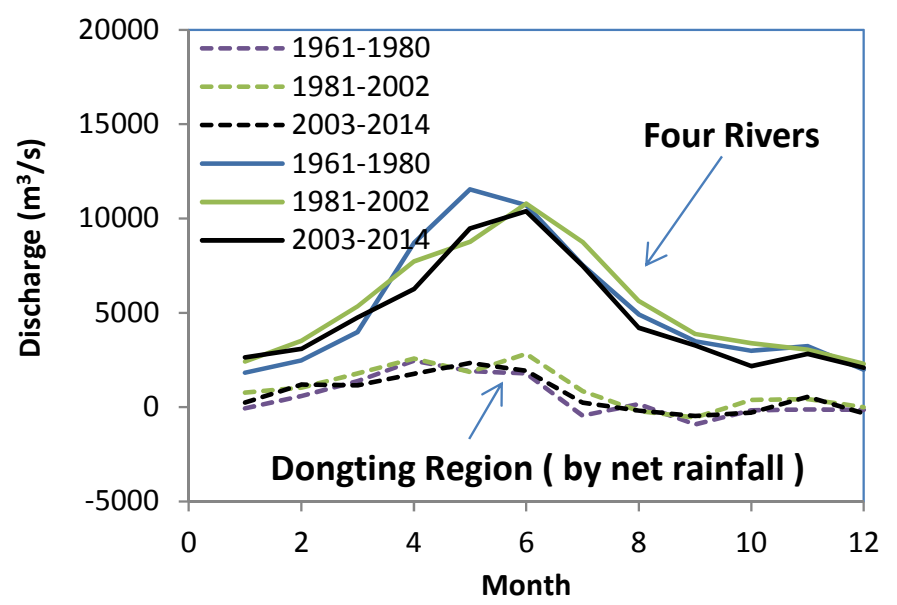

Figure 11. Comparison between total inflow from four rivers and net rainfall induced inflow around Dongting Lake.

\section{Discussion}

\subsection{The Analysis on Water Level Changing Trend}

The analysis revealed changes in the mean annual water level throughout the entire time series, as presented in Figure 2 and Table 2. WLM generally increased, especially during the 1990s, WLM progressively increased, but during the 2000s, the water level began to decrease. The change in water level in the last two sub-periods has some relationship with the change in net precipitation around Dongting Lake (Figures 10 and 11). Considering the change trend in water levels (Figure 2 and Table 2) and the reduce inflow into the lake during the wet season (Figure 7c-e), future flood periods may occur less often. Although WL progressively increased, we noticed that WLm increased more significantly, particularly from the 1980s on. From December until June, the reservoirs discharged more water to the downstream, increasing the water level in Dongting Lake $[17,60]$. Obviously, low water levels increased substantially from 1980s, perhaps reducing the hydrological conditions that would allow droughts to occur. As a direct result, drought events will probably happen less frequently in the future.

The analyses in Figures 3 and 5 indicate that the range between WLM and WLm decreases over time. These two figures also show a continuous decrease in Cv over time, but during the 1990s, this hydrological variable was very high. Clearly, the dispersion of annual water level around the mean becomes very low in later sub-periods, but during the 1990s, the range between WLM and WLm is high. These analyses prove the presence of large changes in the annual water level of the Dongting Lake and may decrease the probability of high and low water levels occurring in the future. However, during the 1990s, the high water level was increasing, mainly driven by the serious rainfall in the flood seasons, especially in 1998 and 1999.

Generally, the changes of water level over the sub-periods obtained via the Pettitt test are similar to the changes over the sub-periods obtained via the operation of TGR. It is evident that the water level in the dry season was subject to greater degrees of increase during the second sub-period compared to the wet season, and the water level in the dry season was subject to greater degrees of increase during the third sub-period (Figure 6 and Table 5). Greater degrees of increase in the dry season can be found during the third sub-period than during the second sub-period, but fewer degrees of increase, even a decreasing trend, can be found in the wet season. For the monthly scale, the maximum monthly average water level over the period 2000-2014 have increased compared to the period 2003-2014 and the minimum monthly average water level over the period 2000-2014 have decreased compared to the period 2003-2014. For the annual scale, WLM, WL, and WLm have increased, but the increasing magnitude of WLM and WL were less compared to WLm. All those shows that the operation of TGR playing an important role to decrease the probability of future drought and flood events. Thus, we can 
conclude tentatively that the Dongting Lake is dominated by less increasing WLM and significantly increasing Wlm with decreasing RA.

\subsection{Identification on the Hydrological Variation Linked to TGR and GZB}

Based on this case study, anthropogenic activities, especially the construction and operation of large reservoirs is one of main driving factor for changes in lake water levels during sub-period 2003-2014, because the following reasons: (1) there is an obvious declining trend in the water level before the start of the dry season in August and November, which is driven by water storage in large reservoirs on the upper reach of the Yangtze River and four branched rivers around Dongting Lake; (2) in the recent several years, low water levels in the dry season increase despite the slight erosion of the lake bed, especially at the narrow navigation region near Chenglingji station [58], indicated that the rise in water level is mainly driven by backwater effect from the increasing flow discharge and water level at Luoshan station in the Yangtze main channel from the release of surplus water from reservoirs at the start of the flood season (Figure 7a,b) together with moderate inflow increase at four rivers (Figure 7c,d); and (3) three sub-periods showed a large variation in high water levels during the flood season, directly and mainly caused by the rainfall, and flood dispatches from an increasing number of large reservoirs in the river basins around Dongting Lake shaped flow discharge and water level processes at some degree. It is not easy to separate quantitatively the variations from rainfall and reservoir operations only using limited measured data. Our modeling scenario results indicated quantitatively the operations of TGR played an important role on the water level changing in Dongting Lake (Figures 8 and 9). The operation of TGR and GZB, especially the 145-175 m operation of TGR, had shaped the water level processes and pushed hydrological process earlier with small RA than before. It may prevent the floods transport from four rivers, speeding up the flow releasing processes from Dongting Lake to Yangtze River at the end of the flood season. Modeling results in the references [61] showed that other existing large reservoirs in the upper Yangtze River could decrease flood water levels by as much as $1.0-3.0 \mathrm{~m}$ at the Chenglingii station and furthermore strengthened the water level shaping at Dongting Lake.

\subsection{Further Evaluation on the Hydrological Variation Linked to Anthropogenic and Climate Factors}

The detailed driving factors for the water levels in worldwide lakes are quite different and there may be combined effects for a specific lake. The causes for water level reduction in individual lakes and wetlands are usually poorly understood and most assuredly are multi-faceted and additive [9]. And, it is difficult to separate the influence of human alterations from climate change and other factors [62]. For example, in China, there are quite different trend for the lakes in Qinghai-Tibet Plateau, Inner-Mongolia, Xinjiang, Northeast Plain of China and East China Plain because of the differences in key controling factors related to the snow or glacier melts, intensified evaporation, intensified western wind in the winter, desertification and aggravated soil erosion, water consumption for agricultural use, etc. [63]. The mutiple forces by precipitation, inflow, the air temperature and evaporation resulted in a decline in water levels in Lake Superior in North America at the rate of approximately $1.0 \mathrm{~cm}$ per year [31]. The water level variation of Poyang Lake in China may be a combination effect by the operation of TGR [64], serious sand mining and waterway regulation [65]; The precipitation in the Huai River basin decreased since the mid-1960s, while the WLM increased significantly. WLM of Hongze Lake has been changed more and more by anthropogenic activities (especially hydraulic engineering) from 1950s [29]. The operations of dams in upper reach of the Yellow river altered the hydrological processes in the middle and lower Yellow river reach [66]. The decline of water level in Urmia Lake in Iran is mainly driven by flow diversion and recent drought in river basin [67].

Our results indicated that water level in Dongting Lake has an increasing trend from 1961 to 2014. However, from 1981 to 2014, this balance changed, perhaps driven by the change of precipitation and the operation of reservoirs. Reservoirs may play an important role on weakening the flood peaks 
and maintaining the ecological water level of the lake. In particular, TGR has resulted in a significant decline in flood water level in the wet season and a significant increase in the dry season, a result that coincides with the reference [34]. Moreover, the related measured flow discharge at period 1961-2014 are collected and processed to identify and analyze qualitatively the key driving factors for the water level variation in Dongting Lake. The inflows around Dongting Lake or rainfall at upper reach of Yangtze rivers and four rivers are main driving force to the annual variation of the water level in Donting Lake. Our numerical modeling results indicated quantitatively the operation of TGR shaped the water level processes especially when the 145-175 scheme was used since 2009. The operation of reservoirs will decrease the RA, and this may decrease the probability of high and low water levels occurring in future. In addition, the hydrological variation in Dongting Lake may also be caused by long-term lake sedimentation, historic reclaimation and river-lake system alteration around Dongting Lake. Futhermore, in recent one decade, the TGR and other large existing reservoirs in the upper Yangtze River caused serious sediment declines in the lower reach of these dams and obvoius erosion appeared especially in the Jingjiang reach, this might decrease water level in Yangtze main channel at some degree. The combined effects of these factors are required to be seperated further and evaluated using more historic measured bathemetry data and an integrated modeling system at next step.

\section{Conclusions}

Long-term statistical analysis of water level variations in Dongting Lake will definitely help to manage the water resources in this large freshwater lake. In this study, we analyzed the trends for seventeen hydrological variables using the MK method. Then, we averaged change points and classified sub-periods using the Pettitt test. Finally, we used Sen's slope test to calculate the magnitude of the trend slope for the key variables in the sub-periods. According to these results, the main conclusions are as follows.

(1) WLM, WL, and WLm show significantly increasing trends from 1961 to 2014; however, different trends appear from 1981 to 2014. For example, in this sub-period, WLm shows a statistically significant increasing trend, but WLM and WL show non-significant decreasing trends.

(2) The annual changing trends of WLM in Dongting Lake occurred at a rate of approximately $0.90 \mathrm{~cm}$ /year and $-2.27 \mathrm{~cm} /$ year from 1961 to 2014 and 1981 to 2014, respectively. The annual changing trends of WL in Dongting Lake occurred at a rate of approximately $1.65 \mathrm{~cm} /$ year and $-0.79 \mathrm{~cm} /$ year from 1961 to 2014 and 1981 to 2014, respectively. The annual increasing trends of WLm in Dongting Lake occurred at a rate of approximately $4.58 \mathrm{~cm} /$ year and $2.56 \mathrm{~cm} /$ year from 1961 to 2014 and 1981 to 2014 , respectively.

(3) The water levels in the dry season are subject to greater degrees of increase during the last two sub-periods when compared to the wet season. However, the water level in the wet season is subject to greater degrees of decrease when compared to the first sub-period. Greater degrees of increase in the dry season were found during the third sub-period than during the second sub-period, but smaller degrees of increase, even a decreasing trend, was found in the wet season, which may be driven by the monthly variation of precipitation in wet season, together with the reservoirs' operations.

(4) Our numerical modeling results indicated that the rise in water level at Dongting Lake in dry season especially since 2009 was mainly driven by backwater effect from the increasing flow discharge and related higher water level at Luoshan station by 145-175 m operation of the TGR.

Long-term changes in the water levels of Dongting Lake may decrease the probability of future drought and flood events. The finding of this study is fundamental and can be used to apply the effective water resource management and ecological protection in Dongting Lake. In next step, using combined methods including measured data mining and scenario simulation by integrated numerical model, further studies will be conducted to quantitatively to identify and predict the long-term and accumulative changing trends of the lake's water level under the dynamical changing river-lake system in the middle Yangtze River and the operations of all the large dams in the upper and middle Yangtze River. 
Acknowledgments: The research reported herein is funded by the National Basic Research Program of China (the NBRP 973 program) (Grant No. 2013CB036406), the Key Project of National Natural Science Foundation of China (Grant No. 91325201) and the National Science Foundation of China (51479010).

Author Contributions: Guoxian Huang and Shuanghu Zhang developed the original ideas. Qiaoqian Han and Rui Zhang undertook the studies and further developed and improved on the original ideas as reported herein. Qiaoqian Han and Guoxian Huang drafted the manuscript, which was revised substantially by all authors.

Conflicts of Interest: The authors declare no conflict of interest.

\section{References}

1. Beeton, A.M. Large freshwater lakes: Present state, trends, and future. Environ. Conserv. 2002, 29, 21-38. [CrossRef]

2. Brönmark, C.; Hansson, L.-A. Environmental issues in lakes and ponds: Current state and perspectives. Environ. Conserv. 2002, 29, 290-306. [CrossRef]

3. Wantzen, K.M.; Rothhaupt, K.-O.; Mörtl, M.; Cantonati, M.; László, G.; Fischer, P. Ecological Effects of Water-Level Fluctuations in Lakes: An Urgent Issue. Hydrobiologia 2008, 613, 1-4. [CrossRef]

4. Williamson, C.E.; Saros, J.E.; Vincent, W.F.; Smold, J.P. Lakes and reservoirs as sentinels, integrators, and regulators of climate change. Limnol. Oceanogr. 2009, 54, 2273-2282. [CrossRef]

5. Coe, M.T.; Foley, J.A. Human and natural impacts on the water resources of the Lake Chad basin. J. Geophys. Res. Atmos. 2001, 106, 3349-3356. [CrossRef]

6. Schindler, D.W. The cumulative effects of climate warming and other human stresses on Canadian freshwaters in the new millennium. Can. J. Fish. Aquat. Sci. 2001, 58, 18-29. [CrossRef]

7. Hampton, S.E.; Izmest, E.; Lyubov, R.; Moore, M.V.; Katz, S.L.; Dennis, B.; Silow, E.A. Sixty years of environmental change in the world's largest freshwater lake-Lake Baikal, Siberia. Glob. Chang. Biol. 2008, 14, 1947-1958. [CrossRef]

8. Ariztegui, D.; Anselmetti, F.S.; Robbiani, J.-M.; Bernasconi, S.; Brati, E.; Gilli, A.; Lehmann, M. Natural and human-induced environmental change in southern Albania for the last 300 years-Constraints from the Lake Butrint sedimentary record. Glob. Planet. Chang. 2010, 71, 183-192. [CrossRef]

9. Coops, H.; Beklioglu, M.; Crisman, T.L. The role of water-level fluctuations in shallow lake ecosystems-Workshop conclusions. Hydrobiologia 2003, 506, 23-27. [CrossRef]

10. Aroviita, J.; Hämäläinen, $\mathrm{H}$. The impact of water-level regulation on littoral macroinvertebrate assemblages in boreal lakes. Hydrobiologia 2008, 613, 45-56. [CrossRef]

11. Baumgärtner, D.; Mörtl, M.; Rothhaupt, K.-O. Effects of water-depth and water-level fluctuations on the macroinvertebrate community structure in the littoral zone of Lake Constance. Hydrobiologia 2008, 613, 97-107. [CrossRef]

12. Van der Valk, A.G. Water-level fluctuations in North American prairie wetlands. Hydrobiologia 2005, 539, 171-188. [CrossRef]

13. Zhang, F.; Tiyip, T.; Johnson, V.C.; Ding, J.-L.; Sun, Q.; Zhou, M.; Kelimu, A.; Nurmuhammat, I.; Chan, N.W. The influence of natural and human factors in the shrinking of the Ebinur Lake, Xinjiang, China, during the 1972-2013 period. Environ. Monit. Assess. 2015, 187, 4128-4141. [CrossRef] [PubMed]

14. Huang, Q.; Jiang, J. Analysis of the Lake Basin Change and the Rushing silting Features in the Past Decades of Dongting Lake. J. Lake Sci. 2004, 3. [CrossRef]

15. Du, Y.; Xue, H.-P.; Wu, S.-J.; Ling, F.; Xiao, F.; Wei, X.-H. Lake area changes in the middle Yangtze region of China over the 20th century. J. Environ. Manag. 2011, 92, 1248-1255. [CrossRef] [PubMed]

16. Liu, X.; Xu, C. Role and Protection of Dongting Lake. Agric. Sci. Technol. 2014, 15, 2220-2225. [CrossRef]

17. Lai, X.; Jiang, J.; Huang, Q. Effects of the normal operation of the Three Gorges Reservoir on wetland inundation in Dongting Lake, China: A modelling study. Hydrol. Sci. J. 2013, 58, 1467-1477. [CrossRef]

18. Cui, M.; Zhou, J.; Huang, B. Benefit evaluation of wetlands resource with different modes of protection and utilization in the Dongting Lake region. Procedia Environ. Sci. 2012, 13, 2-17. [CrossRef]

19. Zhao, S.; Fang, J.; Miao, S.; Gu, B.; Tao, S.; Peng, C.; Tang, Z. The 7-decade degradation of a large freshwater lake in Central Yangtze River, China. Environ. Sci. Technol. 2005, 39, 431-436. [CrossRef] [PubMed]

20. Leira, M.; Cantonati, M. Effects of water-level fluctuations on lakes: An annotated bibliography. Hydrobiologia 2008, 613, 171-184. [CrossRef] 
21. Keddy, P.; Reznicek, A. Great Lakes vegetation dynamics: The role of fluctuating water levels and buried seeds. J. Gt. Lakes Res. 1986, 12, 25-36. [CrossRef]

22. Keough, J.R.; Thompson, T.A.; Guntenspergen, G.R.; Wilcox, D.A. Hydrogeomorphic factors and ecosystem responses in coastal wetlands of the Great Lakes. Wetlands 1999, 19, 821-834. [CrossRef]

23. Casanova, M.T.; Brock, M.A. How do depth, duration and frequency of flooding influence the establishment of wetland plant communities? Plant Ecol. 2000, 147, 237-250. [CrossRef]

24. Wilcox, D.A. Implications of hydrologic variability on the succession of plants in Great Lakes wetlands. Aquat. Ecosyst. Health Manag. 2004, 7, 223-231. [CrossRef]

25. Gafny, S.; Gasith, A.; Goren, M. Effect of water level fluctuation on shore spawning of Mirogrex terraesanctae (Steinitz), (Cyprinidae) in Lake Kinneret, Israel. J. Fish Biol. 1992, 41, 863-871. [CrossRef]

26. Gafny, S.; Gasith, A. Spatially and temporally sporadic appearance of macrophytes in the littoral zone of Lake Kinneret, Israel: Taking advantage of a window of opportunity. Aquat. Bot. 1999, 62, 249-267. [CrossRef]

27. Wantzen, K.M.; de Arruda Machado, F.; Voss, M.; Boriss, H.; Junk, W.J. Seasonal isotopic shifts in fish of the Pantanal wetland, Brazil. Aquat. Sci. 2002, 64, 239-251. [CrossRef]

28. Bond, N.R.; Lake, P.; Arthington, A.H. The impacts of drought on freshwater ecosystems: An Australian perspective. Hydrobiologia 2008, 600, 3-16. [CrossRef]

29. Yin, Y.; Chen, Y.; Yu, S.; Xu, W.; Wang, W.; Xu, Y. Maximum water level of Hongze Lake and its relationship with natural changes and human activities from 1736 to 2005. Quat. Int. 2013, 304, 85-94. [CrossRef]

30. Pasquini, A.I.; Lecomte, K.L.; Depetris, P.J. Climate change and recent water level variability in Patagonian proglacial lakes, Argentina. Glob. Planet. Chang. 2008, 63, 290-298. [CrossRef]

31. Motiee, H.; McBean, E. An assessment of long-term trends in hydrologic components and implications for water levels in Lake Superior. Hydrol. Res. 2009, 40, 564-579. [CrossRef]

32. Haghighi, A.T.; Kløve, B. A sensitivity analysis of lake water level response to changes in climate and river regimes. Limnol. Ecol. Manag. Inland Waters 2015, 51, 118-130. [CrossRef]

33. Li, X.; Zhang, Q.; Xu, C.-Y.; Ye, X. The changing patterns of floods in Poyang Lake, China: Characteristics and explanations. Nat. Hazards 2015, 76, 651-666. [CrossRef]

34. Yuan, Y.; Zeng, G.; Liang, J.; Huang, L.; Hua, S.; Li, F.; Zhu, Y.; Wu, H.; Liu, J.; He, X.; et al. Variation of water level in Dongting Lake over a 50-year period: Implications for the impacts of anthropogenic and climatic factors. J. Hydrol. 2015, 525, 450-456. [CrossRef]

35. Wang, X.; Yan, D.; Xiao, W.; Zhu, W.; Yuan, Y. Evolution of the Hydrological and Hydrodynamic Characteristics in the Outlet Reach of Xiangjiang River. J. Environ. Ecol. 2012, 3, 137-148. [CrossRef]

36. Hayashi, S.; Murakami, S.; Xu, K.-Q.; Watanabe, M. Effect of the Three Gorges Dam Project on flood control in the Dongting Lake area, China, in a 1998-type flood. J. Hydro-Environ. Res. 2008, 2, 148-163. [CrossRef]

37. Mann, H.B. Nonparametric tests against trend. Econom. J. Econom. Soc. 1945, 13, 245-259. [CrossRef]

38. Kendall, M.G. Rank Correlation Methods; Griffin: London, UK, 1975; p. 202.

39. Pettitt, A. A non-parametric approach to the change-point problem. Appl. Stat. 1979, 28, 126-135. [CrossRef]

40. Sen, P.K. Estimates of the regression coefficient based on Kendall's tau. J. Am. Stat. Assoc. 1968, 63, 1379-1389. [CrossRef]

41. Hirsch, R.M.; Slack, J.R.; Smith, R.A. Techniques of trend analysis for monthly water quality data. Water Resour. Res. 1982, 18, 107-121. [CrossRef]

42. Theil, H. A rank-invariant method of linear and polynomial regression analysis. In Henri Theil's Contributions to Economics and Econometrics; Springer: London, UK, 1992; pp. 345-381.

43. Adler, J. R in a Nutshell: A Desktop Quick Reference; O'Reilly Media, Inc.: Sebastopol, CA, USA, 2010.

44. Burn, D.H.; Elnur, M.A.H. Detection of hydrologic trends and variability. J. Hydrol. 2002, 255, $107-122$. [CrossRef]

45. Von Storch, H. Misuses of Statistical Analysis in Climate Research; Springer: New York, NY, USA, 1999; pp. 11-26.

46. Gocic, M.; Trajkovic, S. Analysis of changes in meteorological variables using Mann-Kendall and Sen's slope estimator statistical tests in Serbia. Glob. Planet. Chang. 2013, 100, 172-182. [CrossRef]

47. Sayemuzzaman, M.; Jha, M.K. Seasonal and annual precipitation time series trend analysis in North Carolina, United States. Atmos. Res. 2014, 137, 183-194. [CrossRef]

48. Pohlert, T. Non-Parametric Trend Tests and Change-Point Detection. CC BY-ND 4.0. Available online: http:/ / creativecommons.org/licenses/by-nd/4.0/ (accessed on 25 March 2015). 
49. Villasenor Alva, J.A.; Estrada, E.G. A generalization of Shapiro-Wilk's test for multivariate normality. Commun. Stat. Theory Methods 2009, 38, 1870-1883. [CrossRef]

50. Bartlett, M.S.; Kendall, D. The statistical analysis of variance-heterogeneity and the logarithmic transformation. Suppl. J. R. Stat. Soc. 1946, 8, 128-138. [CrossRef]

51. Qasim, A.; Nisar, S.; Shah, A.; Khalid, M.S.; Sheikh, M.A. Optimization of process parameters for machining of AISI-1045 steel using Taguchi design and ANOVA. Simul. Model. Pract. Theory 2015, 59, 36-51. [CrossRef]

52. Gupta, N.K.; Jethoo, A.; Gupta, S. Rainfall and surface water resources of Rajasthan State, India. Water Policy 2016, 18, 276-287. [CrossRef]

53. Hoaglin, D.C.; Welsch, R.E. The hat matrix in regression and ANOVA. Am. Stat. 1978, 32, 17-22.

54. Zhang, R.; Zhang, S.-H.; Xu, W.; Wang, H. Flow regime of the three outlets on the south bank of Jingjiang River, China: An impact assessment of the Three Gorges Reservoir for 2003-2010. Stoch. Environ. Res. Risk Assess. 2015, 29, 2047-2060. [CrossRef]

55. Huang, G.; Zhou, J.; Lin, B.; Xu, X.; Zhang, S. Modelling hydrographic processes of large lowland river networks: With the middle and lower Yangtze River as an example. Water Manag. 2016, 1-12. [CrossRef]

56. Huang, G.; Zhou, J.; Lin, B.; Chen, Q.; Falconer, R. Distributed Numerical Hydrological and Hydrodynamic Modelling for Large River Catchment. In Proceedings of the 35th IAHR World Congress, Chengdu, China, 9-13 September 2013; pp. 1-12.

57. Huang, G. Development and Application of the Flow Model for the Complex River Networks in the Middle Yangtze River; Post-Doctor Reprot; Department of Hydraulic Engineering, Tsinghua University: Beijing, China, 2008; pp. 1-99. (In Chinese)

58. Zhu, L.; Chen, J.; Yuan, J.; Dong, B. Sediment erosion and deposition in two lakes connected with the middle Yangtze River and the impact of Three Gorges Reservoir. Adv. Water Sci. 2014, 25, 348-357. (In Chinese)

59. Jiang, C.; Li, C.; Li, Z.; Long, Y. Study of fluvial processes in Xiangtan-Haohekou Section of Xiangjiang River. J. Sediment Res. 2013, 3, 19-26. (In Chinese) [CrossRef]

60. Li, S.; Xiong, L.; Dong, L.; Zhang, J. Effects of the Three Gorges Reservoir on the hydrological droughts at the downstream Yichang station during 2003-2011. Hydrol. Process. 2013, 27, 3981-3993. [CrossRef]

61. Huang, G.; Jin, Y.; Zhou, J.; Chen, Q. Quantitative Calculation of Hydrological Variation in Middle and Lower Yangtze River (MLYR) Under the Action of Large Cascade Reservoirs (LCR). In Proceedings of the 3rd International Conference on Estuaries \& Coasts, ICEC, Sendai, Japan, 14-16 September 2009; pp. 569-576.

62. Hollis, G.; Stevenson, A. The physical basis of the Lake Mikri Prespa systems: Geology, climate, hydrology and water quality. Hydrobiologia 1997, 351, 1-19. [CrossRef]

63. Wang, X.; Gong, P.; Zhao, Y.; Xu, Y.; Cheng, X.; Niu, Z.; Luo, Z.; Huang, H.; Sun, F.; Li, X. Water-level changes in China's large lakes determined from ICESat/GLAS data. Remote Sens. Environ. 2013, 132, 131-144. [CrossRef]

64. Mei, X.; Dai, Z.; Du, J.; Chen, J. Linkage between Three Gorges Dam impacts and the Dramatic Recessions in China's Largest Freshwater Lake, Poyang Lake. Sci. Rep. 2015, 5, 1-9. [CrossRef] [PubMed]

65. Lai, X.; Shankman, D.; Huber, C.; Yesou, H.; Huang, Q.; Jiang, J. Sand mining and increasing Poyang Lake's discharge ability: A reassessment of causes for lake decline in China. J. Hydrol. 2014, 519, 1698-1706. [CrossRef]

66. Yang, T.; Zhang, Q.; Chen, Y.D.; Tao, X.; Xu, C.Y.; Chen, X. A spatial assessment of hydrologic alteration caused by dam construction in the middle and lower Yellow River, China. Hydrol. Process. 2008, 22, 3829-3843. [CrossRef]

67. Hassanzadeh, E.; Zarghami, M.; Hassanzadeh, Y. Determining the main factors in declining the Urmia Lake level by using system dynamics modeling. Water Resour. Manag. 2012, 26, 129-145. [CrossRef]

(C) 2016 by the authors; licensee MDPI, Basel, Switzerland. This article is an open access article distributed under the terms and conditions of the Creative Commons Attribution (CC-BY) license (http://creativecommons.org/licenses/by/4.0/). 